\title{
ANALIZA MOŻLIWOŚCI ZWIĘKSZENIA UDŹWIGU UŻYTECZNEGO SAMOLOTU SU-22 ORAZ MIG-29 DLA POTRZEB LOTNICZO-RAKIETOWEGO SYSTEMU WYNOSZENIA SATELITÓW NA NISKĄ ORBITĘ OKOŁOZIEMSKĄ
}

\author{
Piotr Zalewski, Michą Jasztal, Robert Rogólski \\ Wojskowa Akademia Techniczna, Wydzial Mechatroniki, Uzbrojenia i Lotnictwa \\ e-mail: piotr.zalewski@wat.edu.pl; michal.jasztal@wat.edu.pl; robert.rogolski@wat.edu.pl
}

\begin{abstract}
Praca stanowi kolejny etap rozwoju koncepcji lotniczo-rakietowego systemu wynoszenia niewielkich satelitów na niską orbitę okołoziemską przy wykorzystaniu samolotów MiG-29 oraz Su-22. W ramach tego etapu podjęto się zadania analizy możliwości zwiększenia udźwigu użytecznego tych samolotów. Stwierdzono, że cel ten można zrealizować, zmniejszając masę własną samolotu poprzez usunięcie elementów jego wyposażenia bojowego. Stąd też przeprowadzono analizę możliwości usunięcia elementów systemu sterowania bronią oraz współpracujących z nim urządzeń wykonawczych. Wykorzystując dokumentację techniczną rozważanych samolotów, dokonano szczegółowej analizy ww. systemów uzbrojenia w aspekcie ich demontażu, a wyniki prac zebrano w tabelach. W ramach pracy dokonano obliczeń wyważenia samolotu MiG-29 po usunięciu wybranych elementów. Do tego celu wykorzystano model masowy CAD samolotu opracowany w systemie NX. Obliczono, iż po demontażu zaproponowanej części wyposażenia bojowego samolotu MiG-29 środek masy całego obiektu misyjnego wędruje do $28 \%$ średniej cięciwy aerodynamicznej, co mieści się w dozwolonym przedziale (23,7\%-30,5\% MAC). W przypadku Su-22 stwierdzono, iż ponad $80 \%$ masy urządzeń wytypowanych do usunięcia leży w pobliżu środka masy samolotu, przez co ich usunięcie nie wpłynie znacząco na wyważenie samolotu.
\end{abstract}

Stowa kluczowe: samolot bojowy, uzbrojenie, analiza masowa, wyważenie samolotu

\section{Wprowadzenie}

Pierwsze przedsięwzięcia mające na celu umieszczenie na orbicie okołoziemskiej obiektu z wykorzystaniem rakiety odpalanej z samolotu były realizowane przez Marynarkę Wojenną USA już pod koniec lat 50. XX wieku [1]-[3]. Najistotniejsze zalety użytkowania lotniczo-rakietowych systemów wynoszenia związane są ze zredukowaniem przyrostu prędkości rakiety wymaganego do wyniesienia obiektu na orbitę oraz brakiem konieczności wznoszenia się rakiety przez najgęstszą część atmosfery z użyciem własnego napędu, co sprawia, że masa niezbędnego paliwa rakiety jest mniejsza. Stąd też na przestrzeni minionych dziesięcioleci można było zaobserwować próby rozwoju kolejnych tego typu rozwiązań [1]-[10].

Opracowana w 2016 r. przez zespół naukowy Wydziału Mechatroniki i Lotnictwa Wojskowej Akademii Technicznej w Warszawie koncepcja lotniczo-rakietowego systemu wynoszenia niewielkich satelitów na niską orbitę okołoziemską bazuje na możliwości wykorzystania eksploatowanych w Polsce samolotów MiG-29 oraz Su-22 M4 [11]-[14]. Wstępne analizy wykazały, iż samoloty te posiadają wymagane osiągi, aby można je przystosować do zadań platformy do wynoszenia rakiet kosmicznych. Obliczenia numeryczne i symulacje wskazują, iż wpływ rakiety kosmicznej na charakterystyki aerodynamiczne, osiągi oraz stateczność podłużną nosicieli (ww. samolotów) jest nieznaczny [12]-[14].

Należy jednak dokonać analizy wyposażenia ww. statków powietrznych pod kątem możliwości demontażu elementów, które są zbędne z punktu widzenia celu misji, np. elementów uzbrojenia 
samolotu. Szacuje się, że usunięcie elementów systemu sterowania bronią oraz współpracujących z nim urządzeń wykonawczych pozwoliłoby zwiększyć udźwig użyteczny nosicieli.

\section{Analiza samolotu MiG-29 pod kątem zwiększenia udźwigu użytecznego}

Badanie możliwości zmniejszenia masy startowej samolotu MiG-29, a przez to zwiększenia jego udźwigu użytecznego, wykonano przy podanych poniżej podstawowych charakterystyk geometryczno-masowych [15].

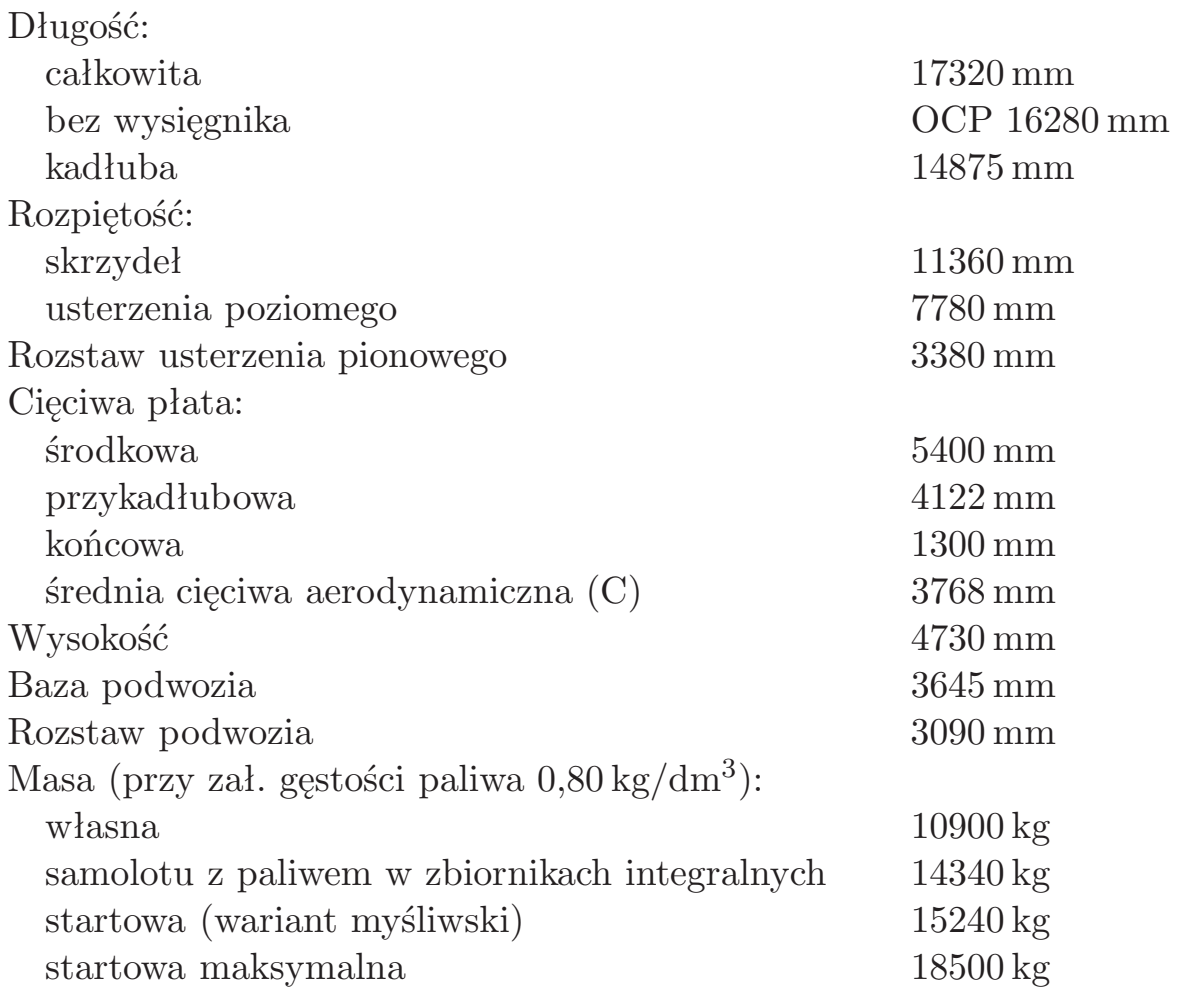

Jak już wspomniano, największe możliwości w zakresie zmniejszenia masy własnej samolotu należy upatrywać w usunięciu elementów jego wyposażenia bojowego. Samolot MiG-29 jest samolotem myśliwskim, którego uzbrojenie stanowi zainstalowane na stałe działko GSz-301 oraz uzbrojenie podwieszane na sześciu węzłach podskrzydłowych (rys. 1).

Podana powyżej w zestawieniu masa własna samolotu jest wyliczona dla tzw. „konfiguracji gładkiej”, czyli bez zewnętrznych elementów stanowisk broni, tj. belek bombardierskich i wyrzutni rakiet. Można jednak dodatkowo usunąć elementy montażowe belek i wyrzutni, które znajdują się częściowo wewnątrz skrzydeł samolotu. Z pewnością należy wziąć pod uwagę demontaż nie tylko samego działka lotniczego, ale również wszystkich elementów stanowiska broni strzeleckiej zawierającego magazyn amunicji, trakty zasilania amunicją, odprowadzania ogniw i łusek itd.

Znaczące możliwości zmniejszenia masy własnej samolotu można również upatrywać w wymontowaniu elementów systemu sterowania bronią, które znajdują się w lukach samolotu i nie sa przydatne w realizacji misji MiGa-29 jako nosiciela rakiety kosmicznej. W celu sprawdzenia istniejących możliwości w tym zakresie dokonano analizy schematu funkcjonalnego systemu sterowania uzbrojeniem samolotu MiG-29. W wyniku prac wydzielone zostały dwa podstawowe podsystemy systemu sterowania uzbrojeniem SSU: radiolokacyjny system celowniczy RŁPK i optyczno-elektroniczny system nawigacyjno-celowniczy 0EPrNK. Zarówno radiolokacyjny system celowniczy, jak i optyczno-elektroniczny system nawigacyjno-celowniczy są silnie zintegro- 


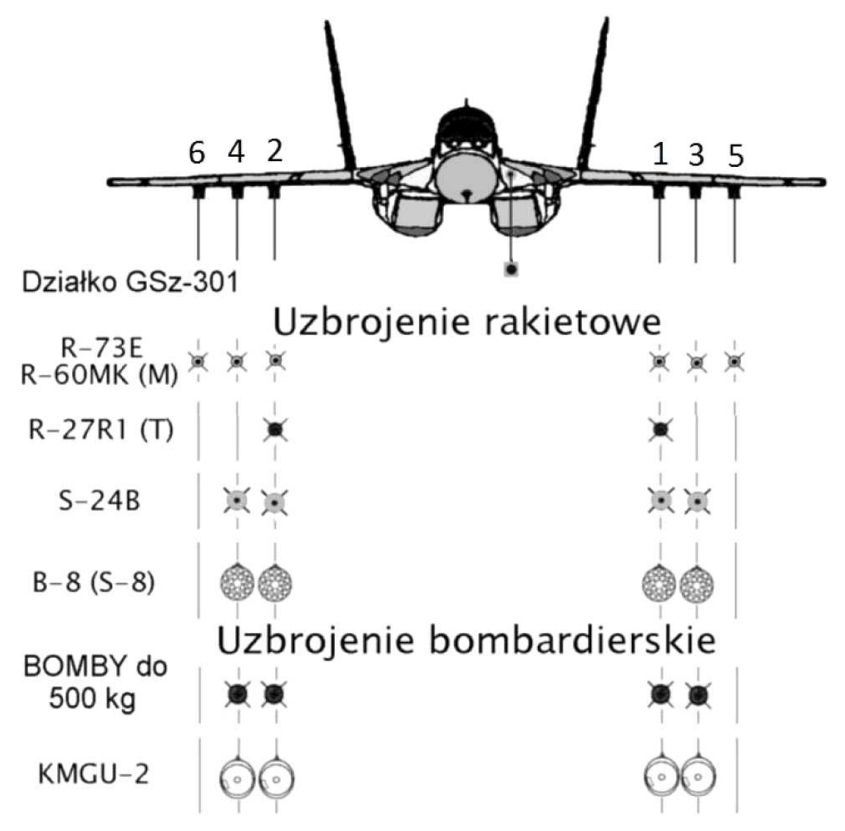

Rys. 1. Stanowiska broni pokładowej samolotu MiG-29 [16]

wane, a konieczność realizacji zadań nawigacyjnych i potrzeba zachowania integralności systemu wyklucza możliwość demontażu kluczowych elementów tych systemów. Inna sytuacja natomiast ma miejsce w przypadku systemu sterowania bronią SSB (SUO), którego rola sprowadza się do zarządzania stanowiskami broni. Demontaż stanowisk broni pokładowej powoduje brak konieczności posiadania aparatury sterującej ich działaniem, ponadto system sterowania bronią nie jest źródłem sygnałów i informacji koniecznych do wykonywania zadań w zakresie „nawigacja”, przez co jego usunięcie nie powinno wpłynąć negatywnie na realizację zadań pilotażowo-nawigacyjnych.

Przeprowadzona analiza wyposażenia samolotu MiG-29 pod kątem możliwości demontażu elementów, które nie będą miały istotnego wpływu na funkcjonowanie systemu pilotażowonawigacyjnego oraz systemu sterowania lotem statku powietrznego, wykazała możliwość usunięcia następujących grup wyposażenia:

- elementy węzłów podwieszeń,

- elementy systemu uzbrojenia strzeleckiego,

- elementy systemu zakłóceń pasywnych,

- urządzenia elektroniczne (bloki) systemu sterowania bronią,

- urządzenia fotokontrolne.

Wykorzystując dokumentacje techniczną samolotu, dokonano szczegółowej analizy ww. systemów uzbrojenia w aspekcie ich demontażu, a wyniki prac zebrano w tabeli 1.

Jak pokazano w tabeli 1, łączna masa urządzeń, które można zdemontować bez znaczącego wpływu na działanie awioniki samolotu MiG-29 w zakresie wykonywania zadań nosiciela, wynosi $259 \mathrm{~kg}$. Zmniejszenie masy samolotu o tę wartość w tzw. konfiguracji gładkiej bez podwieszeń z pilotem oraz zatankowanymi zbiornikami paliwa wewnątrz kadłuba i w skrzydłach z pewnością zwiększy udźwig użyteczny tego samolotu i nie wymaga skomplikowanych zabiegów związanych z przebudową systemów samolotu oraz nie wpłynie na bezpieczeństwo lotu.

Konieczne staje się jednak dokonanie obliczeń wyważenia samolotu po usunięciu elementów wymienionych w tabeli 1 . Do tego celu został wykorzystany model masowy samolotu MiG-29 opracowany w pracy [17], który umożliwia:

- określenie przemieszczania środka masy obiektu samolotu i jego wpływu na zrównoważenie masowo-aerodynamiczne samolotu w locie; 
Tabela 1. Spis urządzeń systemu uzbrojenia wytypowanych do demontażu wraz z podaniem ich masy oraz współrzędnych środka masy (względem układu współrzędnych na rys. 3) [17]

\begin{tabular}{|c|c|c|c|}
\hline $\mathrm{Nr}$ & Nazwa elementu & $\begin{array}{c}\text { Współrzędne środka } \\
\text { masy }(x, y, z)\end{array}$ & $\begin{array}{c}\text { Masa } \\
{[\mathrm{kg}]}\end{array}$ \\
\hline \multicolumn{4}{|c|}{ Węzły podwieszeń } \\
\hline 1 & Przedni węzeł wew. L - 1pp (1L) & $(9265,-2344,74)$ & 5 \\
\hline 2 & Przedni węzeł wew. $\mathrm{P}-2 \mathrm{pp}(1 \mathrm{P})$ & $(9265,2344,74)$ & 5 \\
\hline 3 & Średni węzeł wew. L - 1pp (2L) & $(10285,-2344,31)$ & 2,5 \\
\hline 4 & Średni węzeł wew. $\mathrm{P}-2 \mathrm{pp}(2 \mathrm{P})$ & $(10285,2344,31)$ & 2,5 \\
\hline 5 & Tylny węzeł wew. L - 1pp (3L) & $(10742,-2344,20)$ & 2 \\
\hline 6 & Tylny węzeł wew. $\mathrm{P}-2 \mathrm{pp}(3 \mathrm{P})$ & $(10742,2344,20)$ & 2 \\
\hline 7 & Przedni węzeł środ. L - 3pp (4L) & $(9828,-3104,60)$ & 5 \\
\hline 8 & Przedni węzeł środ. P - 4pp (4P) & $(9828,3104,60)$ & 5 \\
\hline 9 & Tylny węzeł środ. L - 3pp (5L) & $(10817,-3104,26)$ & 5 \\
\hline 10 & Tylny węzeł środ. P - 4pp (5P) & $(10817,3104,26)$ & 5 \\
\hline 11 & Przedni węzeł zew. L - 5pp (6L) & $(10458,-3954,40)$ & 5 \\
\hline 12 & Przedni węzeł zew. P - 6pp (6P) & $(10458,3954,40)$ & 5 \\
\hline 13 & Tylny węzeł zew. L - 5pp (7L) & $(11442,-3954,15)$ & 5 \\
\hline 14 & Tylny węzeł zew. P - 6pp (7P) & $(11442,3954,15)$ & 5 \\
\hline \multicolumn{4}{|c|}{ Uzbrojenie strzeleckie } \\
\hline 15 & Działko GSz-301 & $(4825,-500,50)$ & 50,9 \\
\hline 16 & Dodatkowy węzeł mocowania & \multirow{7}{*}{$(5570,-400,100)$} & 2,5 \\
\hline 17 & Rękaw odprowadzania ogniw & & 1,5 \\
\hline 18 & Głowica rękawa zasilania & & 3 \\
\hline 19 & Przedni węzeł mocowania & & 5,8 \\
\hline 20 & Tylny węzeł z rękawem odprowadzania łusek & & 6 \\
\hline 21 & Rękaw zasilania & & 6 \\
\hline 22 & Zespół odbiorczy rękawa zasilania & & 6 \\
\hline 23 & Skrzynka amunicyjna & $(4890,0,15)$ & 58,2 \\
\hline 24 & Wentylacja działka & $(5400,-400,100)$ & 1 \\
\hline \multicolumn{4}{|c|}{ Urządzenie zakłóceń pasywnych } \\
\hline 25 & Blok ładunków zakłócających & $\begin{array}{c}(9435 ;-1684 ; 287,5) \\
(9435 ; 1684 ; 287,5) \\
\end{array}$ & 22 \\
\hline 26 & Przyrząd PUS & $\begin{array}{c}(9065,-1685,289) \\
(9065,1685,289)\end{array}$ & 1,3 \\
\hline 27 & Pulpit przygotowania danych PPD-SP & $(8030,-795,172)$ & 0,7 \\
\hline \multicolumn{4}{|c|}{ System sterowania bronią SUO-29M1 } \\
\hline 28 & Blok sterowania BSF & \multirow{5}{*}{$(7020,0,547)$} & 6 \\
\hline 29 & Blok sterowania BUR 1 & & 7 \\
\hline 30 & Blok sterowania BUR 2 & & 7 \\
\hline 31 & Rama BM & & 6 \\
\hline 32 & Blok sterowania działkiem BAP & & 2,5 \\
\hline \multicolumn{4}{|c|}{ Urządzenie fotokontrolne } \\
\hline 33 & Fotokamera FKP-JeU & \multirow{2}{*}{$(4890,0,315)$} & \multirow{2}{*}{7,2} \\
\hline 34 & Blok BU-FKP-JeU & & \\
\hline \multicolumn{3}{|c|}{ Łączna masa urządzeń do demontażu: } & $259 \mathrm{~kg}$ \\
\hline
\end{tabular}


- określenie zmiany rozkładu obciążeń masowych, a w efekcie wypadkowych obciążeń bieżących na poszczególne komponenty płatowca;

- określenie wpływu wspomnianych zmian na masowe momenty bezwładności, które mają wpływ na dynamikę samolotu w locie.

Opracowany w ramach pracy [17] model masowy samolotu uwzględnia zarówno elementy struktury, napędu, jak również awioniki i wyposażenia samolotu MiG-29. Dokonując rozmieszczenia w powstałym modelu mas urządzeń radioelektronicznych, systemów mechanicznoenergetycznych, elementów składowych instalacji, wyposażenia wewnętrznego, skorzystano z tabelarycznego spisu tych urządzeń [17], z uwzględnieniem współrzędnych definiujących położenie środków mas komponentów. Masy skupione w modelu CAD zostały wprowadzone w postaci kul o odpowiednich masach (rys. 2). Podane współrzędne zdefiniowane są w układzie, którego początek określono u nasady rurki Pitota, tak jak pokazano na rys. 3.

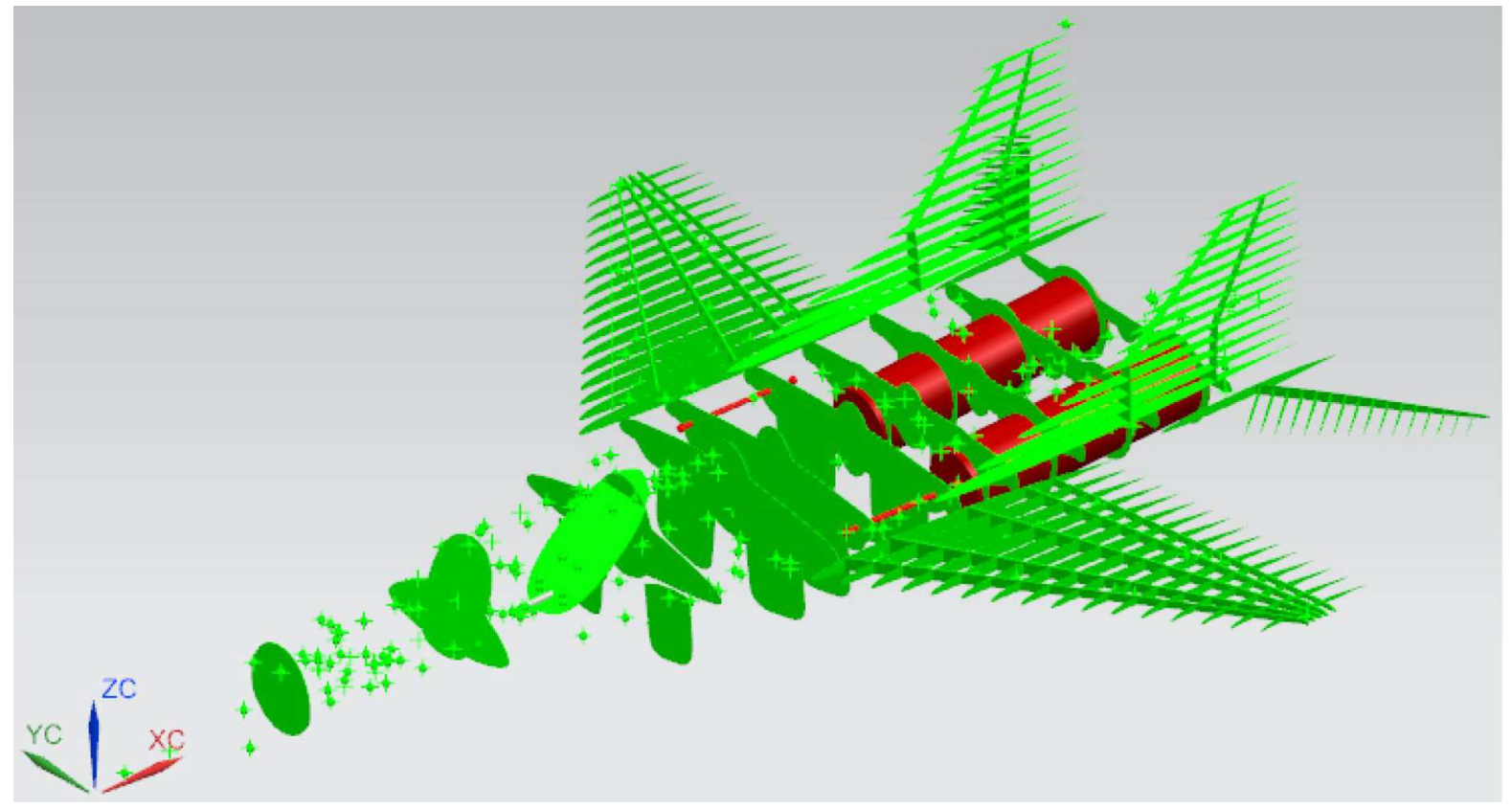

Rys. 2. Widok modelu masowego samolotu MiG-29 z ukrytymi elementami pokrycia i widocznymi kulami zapewniającymi rozkład mas elementów wyposażenia statku powietrznego [17]

W wyniku ostatecznej walidacji modelu masowego uzyskano masę i położenie środka masy samolotu, którą podano w tabeli 2.

Tabela 2. Ostateczna masa samolotu i współrzędne środka masy przyjęte do analizy [17]

\begin{tabular}{|l|c|}
\hline Masa własna $[\mathrm{kg}]$ & 10814 \\
\hline Współrzędna $X$ środka masy $[\mathrm{mm}]$ & 9393 \\
\hline Współrzędna $Y$ środka masy $[\mathrm{mm}]$ & $-3,8$ \\
\hline Współrzędna $Z$ środka masy $[\mathrm{mm}]$ & 185 \\
\hline
\end{tabular}

Wyważenie samolotu MiG-29 zbadano w dwóch konfiguracjach: wariant gotowości do lotu, tj. pilot w kabinie oraz pełne zbiorniki paliwa (bez uwzględnienia podwieszenia rakiety kosmicznej), a także wariant po demontażu wybranych zespołów - samolot z pilotem i paliwem, ze zmniejszoną masą wyposażenia.

Położenie środka masy samolotu określono w odniesieniu do średniej cięciwy aerodynamicznej (ang. Mean Aerodynamic Chord - MAC, pol. - SCA) [18]. Wyznaczono ją uproszczoną metodą wykreślną przedstawioną na rys. 4. Następnie, wykorzystując model samolotu MiG-29 


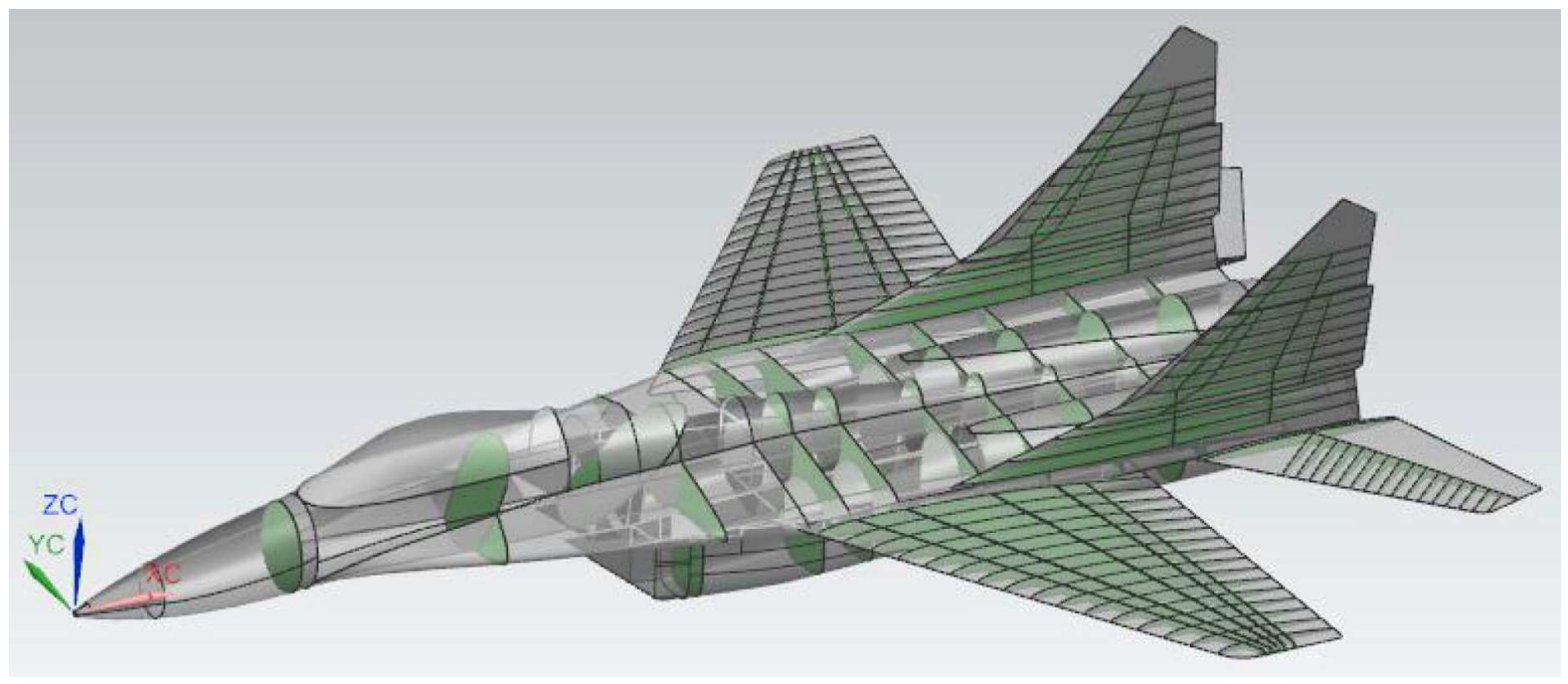

Rys. 3. Lokalizacja początku układu współrzędnych, według którego definiowano położenie poszczególnych elementów wyposażenia samolotu MiG-29 [17]

w systemie Siemens NX, określono współrzędne $X$ początku średniej cięciwy aerodynamicznej (ang. Leading Edge Mean Aerodynamic Chord - LEMAC) oraz jej końca (ang. Trailing Edge Mean Aerodynamic Chord - TEMAC) [5]. Uzyskane wartości geometryczne średniej cięciwy aerodynamicznej przedstawiono $\mathrm{w}$ tabeli 3 .

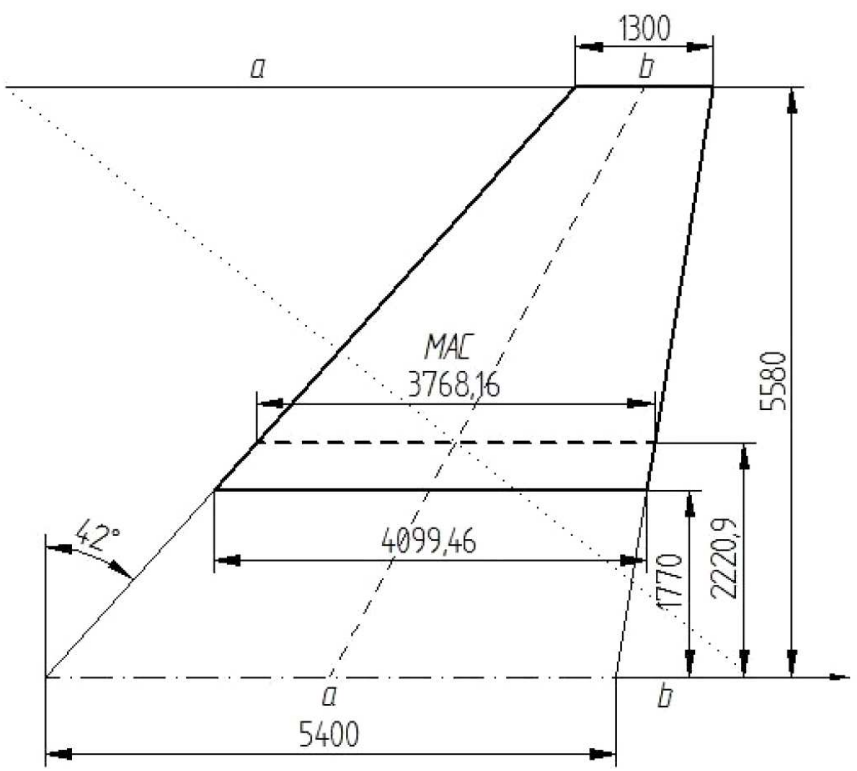

Rys. 4. Wyznaczanie średniej cięciwy aerodynamicznej (MAC) skrzydła samolotu MiG-29 metodą graficzną $[17]$

Tabela 3. Współrzędne $X$ początku i końca średniej cięciwy aerodynamicznej MAC [17]

\begin{tabular}{|l|c|}
\hline Współrzędna $X$ początku MAC $[\mathrm{mm}]$ & 8380 \\
\hline Współrzędna $X$ końca MAC $[\mathrm{mm}]$ & 12148 \\
\hline Długość MCA $[\mathrm{mm}]$ & 3768 \\
\hline
\end{tabular}


Jak już wspomniano, przygotowano modele masowe w dwóch konfiguracjach:

1) samolot gotowy do startu (paliwo w zbiornikach integralnych, pilot w kabinie),

2) samolot w wariancie po demontażu wybranych zespołów - samolot z pilotem i paliwem ze zmniejszoną masą wyposażenia.

Samolot MiG-29 posiada cztery zbiorniki integralne kadłubowe i po jednym zbiorniku integralnym w każdym ze skrzydeł; łącznie mieści w nich 4160 litrów paliwa [19]. W modelu samolotu w systemie NX utworzono punkty o współrzędnych odpowiadających środkom mas odpowiednich objętości paliwa. W punktach tych wygenerowano kule o odpowiedniej objętości i gęstości, które stały się odpowiednikami masy paliwa mieszczącej się w każdym zbiorniku. Dokładny spis mas paliwa został przedstawiony w tabeli 4 .

Tabela 4. Lista zbiorników paliwa samolotu MiG-29 wraz z ich objętościami, masami paliwa uwzględnionego w analizie oraz ze współrzędnymi środków mas poszczególnych objętości paliwa (masę paliwa obliczono, zakładając jego gęstość $\rho=800 \mathrm{~kg} / \mathrm{m}^{3}$ ) [19]

\begin{tabular}{|l|c|c|}
\hline Zbiornik & $\begin{array}{c}\text { Masa } \\
{[\mathrm{kg}]}\end{array}$ & $\begin{array}{c}\text { Współrzędna X środka } \\
\text { masy paliwa }[\mathrm{mm}]\end{array}$ \\
\hline \hline Wewnętrzny nr 1 (640 l) & 512 & 7946 \\
\hline Wewnętrzny nr 2 (875 l) & 700 & 8750 \\
\hline Wewnętrzny nr 3 (1720 l) & 1376 & 9970 \\
\hline Wewnętrzny nr 3a (285 l) & 228 & 11400 \\
\hline Skrzydłowy (2×320 l) & 512 & 10190 \\
\hline
\end{tabular}

Mase pilota ustalono na $90 \mathrm{~kg}$, a jego środek masy ulokowano w przestrzeni fotela katapultowego. Tak przygotowany model w systemie Siemens NX posłużył do zbadania położenia środka masy samolotu przy wybranych konfiguracjach masowych.

Lokalizację środka masy wyrażoną procentem średniej cięciwy aerodynamicznej $M A C$ oszacowano, znając odległość od płaszczyzny odniesienia $Y C-Z C$, odległość środka masy od płaszczyzny odniesienia $Y C-Z C$ oraz długość $M A C$. Zastosowano następującą formułę, wykorzystującą anglojęzyczne skróty [18]

$$
C G \text { in } \% M A C=[(C G-L E M A C) / M A C] \cdot 100 \%
$$

gdzie:

$C G$ (ang. Center of Gravity) - odległość środka masy od płaszczyzny $Y C$ - ZC [mm],

$L E M A C$ - odległość punktu początkowego średniej cięciwy aerodynamicznej od płaszczyzny $Y C-Z C[\mathrm{~mm}]$,

$M A C$ - długość średniej cięciwy aerodynamicznej [mm].

W tabeli 5 przedstawiono położenie środka masy samolotu dla dwóch konfiguracji masy samolotu. W przypadku samolotu z pilotem oraz napełnieniu zbiorników paliwem wypadkowy środek masy samolotu osiąga 26,8\% średniej cięciwy aerodynamicznej. Po demontażu zaproponowanej części wyposażenia bojowego samolotu środek masy całego obiektu misyjnego wędruje do $28 \%$ średniej cięciwy aerodynamicznej.

Posiłkując się dokumentacją techniczną samolotu MiG-29 niemieckich sił powietrznych, gdzie podano dozwolony przedzial wędrówki środka masy w granicach 23,7\%-30,5\% MAC, można stwierdzić, że jego przemieszczenie po demontażu wybranych elementów zawiera się w podanym zakresie [19]. Wędrówka środka masy jest nieznaczna, co jest pożądane, gdyż charakterystyki sterowności obiektu misyjnego nie ulegają dużym zmianom. 
Tabela 5. Zestawienie masy obiektu misyjnego oraz położenia środka masy (ŚM) względem średniej cięciwy aerodynamicznej dla wybranych konfiguracji załadunku samolotu MiG-29 [opracowanie własne]

\begin{tabular}{|l|c|c|c|}
\hline Konfiguracja & $\begin{array}{c}\text { Masa obiektu } \\
\text { misyjnego }[\mathrm{kg}]\end{array}$ & $\begin{array}{c}\text { Współrzędna } X \\
\text { SM }[\% M A C]\end{array}$ & $\begin{array}{c}\text { Odległość ŚM względem } \\
\text { układu odniesienia [mm] }\end{array}$ \\
\hline \hline $\begin{array}{l}\text { Samolot gotowy do startu } \\
\text { zbiorniki napełnione } \\
\text { paliwem, pilot w kabinie) }\end{array}$ & 14232 & 26,8 & 9390,3 \\
\hline $\begin{array}{l}\text { Samolot gotowy do startu } \\
\text { po demontażu wyposażenia }\end{array}$ & 13973 & 28,0 & 9435,5 \\
\hline
\end{tabular}

\section{Analiza samolotu Su-22 pod kątem zwiększenia udźwigu użytecznego}

Punktem wyjścia do badania możliwości zmniejszenia masy startowej samolotu Su-22, a przez to zwiększenia jego udźwigu użytecznego, będzie zastosowanie przedstawionych poniżej jego podstawowych charakterystyk geometryczno-masowych [20].

\section{Wymiary}

$\begin{array}{ll}\text { Długość: } & \\ \text { bez OCP } & 17341 \mathrm{~mm} \\ \text { z OCP } & 19020 \mathrm{~mm} \\ \text { kadłuba } & 15572 \mathrm{~mm} \\ \text { Rozpiętość: } & 13680 \mathrm{~mm} \\ \text { skrzydeł (przy skosie } 30^{\circ} \text { ) } & 10025 \mathrm{~mm} \\ \text { skrzydeł (przy skosie } 63^{\circ} \text { ) } & 4646 \mathrm{~mm} \\ \text { usterzenia poziomego } & 5129 \mathrm{~mm} \\ \text { Wysokość } & 5247 \mathrm{~mm} \\ \text { Baza podwozia } & 3830 \mathrm{~mm} \\ \text { Rozstaw kół podwozia głównego } & \end{array}$

Masy

Masa pustego samolotu

$10980 \mathrm{~kg}$

Masa startowa samolotu (bez podwieszeń z $3030 \mathrm{~kg}$ paliwa) $14817 \mathrm{~kg}$

Maksymalna masa startowa samolotu

$18700 \mathrm{~kg}$

Normalna masa samolotu do lądowania

$12120 \mathrm{~kg}$

Maksymalna masa samolotu do lądowania

$13400 \mathrm{~kg}$

Maksymalna dopuszczalna masa samolotu do lądowania $\quad 14800 \mathrm{~kg}$

Jak już wspomniano, największe możliwości w zakresie zmniejszenia masy własnej samolotu należy upatrywać w usunięciu elementów jego wyposażenia bojowego. Samolot Su-22 jest samolotem myśliwsko-bombowym, którego uzbrojenie stanowią zainstalowane na stałe dwa działka NR-30 oraz uzbrojenie podwieszane na dziesięciu węzłach podkadłubowych i podskrzydłowych (rys. 5). Dodatkowo na kadłubie zainstalowane są wyrzutnie systemu zakłóceń pasywnych.

Działka typu NR-30 zamontowane są w skrzydłach przy nasadzie ich wolnonośnej części w osi cięciwy. Amunicja doprowadzana jest przez rękawy zamontowane wokół kadłuba. Podczas strzelania łuski wyrzucane są pod skrzydło samolotu, a ogniwa układane do specjalnego zbieracza ogniw. W garbie, za kabiną, zamontowane są kasety wyrzutni pułapek termicznych KDS (zawierające $2 \times 6$ nabojów), zaś na kadłubie, symetrycznie do osi podłużnej samolotu, montowane są parami belki ASO-2W (zawierające $8 \times 32$ nabojów), służące do tego samego 


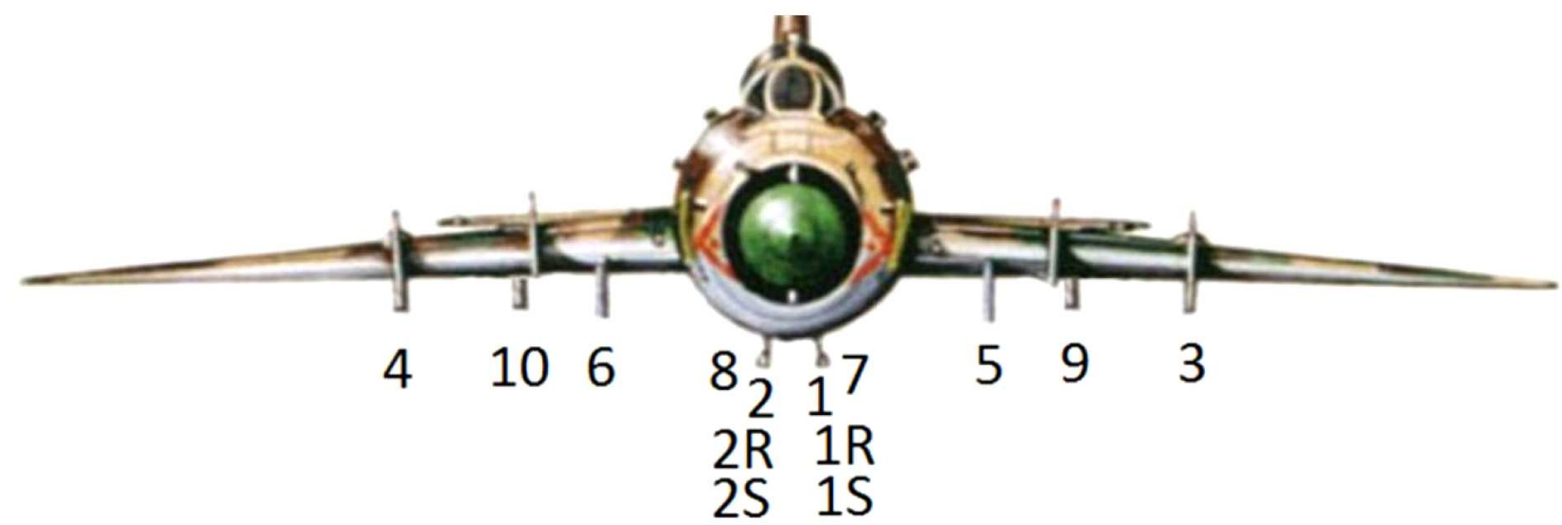

Rys. 5. Stanowiska broni pokładowej samolotu Su-22 (opis w tekście) [21]

celu. Dla uzbrojenia podwieszanego rozmieszczono dziesięć punktów mocowania, z wykorzystaniem których przewidziano ponad sto wariantów uzbrojenia samolotu. Mają one następującą numerację (rys. 5): 1 - lewy podkadłubowy przedni, 2 - prawy podkadłubowy przedni, 3 - lewy podskrzydłowy zewnętrzny, 4 - prawy podskrzydłowy zewnętrzny, 5 - lewy podskrzydłowy wewnętrzny, 6 - prawy podskrzydłowy wewnętrzny, 7 - lewy podkadłubowy tylny, 8 - prawy podkadłubowy tylny, 9 - lewy podskrzydłowy środkowy, 10 - prawy podskrzydłowy środkowy. W punktach 1-8 mocowane są najpierw belki nośne BD3-57MT lub BD3-57MTA, a do nich bezpośrednio uzbrojenie niekierowane i zbiorniki paliwa lub wyrzutnie uzbrojenia kierowanego, podwieszanego dopiero do tych ostatnich. Środkowe punkty podwieszeń (nr 9 i 10) przeznaczone są wyłącznie dla wyrzutni APU-60-lM z kierowanymi pociskami rakietowymi R-60. Wykorzystanie łączne wewnętrznych otworów punktów 1 i 7 oraz 2 i 8 określane jest jako punkty 1s i 2s, natomiast po bokach 7 i 8 występują osobne punkty 1r i 2 r.

W niniejszym opracowaniu rozważana będzie masa samolotu Su-22 w konfiguracji bez podwieszonych środków bojowych i zewnętrznych zbiorników paliwa, z pilotem, z zatankowanymi zbiornikami paliwa wewnątrz kadłuba i w skrzydłach oraz z zamontowanymi belkami bombardierskimi na 1-6 punkcie podwieszenia. W ramach zwiększania udźwigu użytecznego samolotu, oprócz prostego w wykonaniu demontażu belek bombardierskich, można dodatkowo usunąć elementy systemu obrony biernej samolotu, tj. kasety systemu KDS oraz ASO-2W. Koniecznie należy wziąć pod uwagę demontaż nie tylko samych działek lotniczych, ale również wszystkich elementów stanowisk broni strzeleckiej zawierających: węzły mocowania działka, rękawy amunicyjne z elementami doprowadzania amunicji, odprowadzania ogniw oraz układy pneumatycznego przeładowania działek, itd.

Dalsze możliwości zmniejszenia masy własnej samolotu można również upatrywać w wymontowaniu dalmierza laserowego oraz elementów systemu sterowania bronią, które znajdują się w lukach samolotu i nie są przydatne w realizacji misji Su-22 jako nosiciela rakiety kosmicznej. Demontaż stanowisk broni pokładowej powoduje brak konieczności posiadania aparatury sterującej ich działaniem, ponadto system sterowania bronią nie jest źródłem sygnałów i informacji koniecznych do wykonywania zadań w zakresie „nawigacja”, przez co usunięcie układów sterowania bronią nie powinno wpłynąć negatywnie na realizację zadań pilotażowo-nawigacyjnych.

Przeprowadzona analiza wyposażenia samolotu MiG-29 pod kątem możliwości demontażu jego elementów, który nie będzie miał istotnego wpływu na funkcjonowanie systemu pilotażowonawigacyjnego oraz systemu sterowania lotem statku powietrznego, wykazała możliwość usunięcia następujących grup elementów:

- belki podwieszeń z elementami montażowymi;

- elementy systemu uzbrojenia strzeleckiego;

- elementy systemu zakłóceń pasywnych; 
- urządzenia systemu sterowania bronią;

- dalmierz laserowy - stacja KLON.

Wykorzystując dokumentację techniczną samolotu [22], dokonano szczegółowej analizy ww. systemów uzbrojenia $\mathrm{w}$ aspekcie ich demontażu, a wyniki prac zebrano w tabeli 6 . Wyszczególniono w niej nazwy zespołów przeznaczonych do usunięcia wraz z podaniem ich masy oraz współrzędnych środka masy (względem początku układu rys. 6). W niniejszej pracy rozważany był wariant startowy samolotu (pilot w kabinie, paliwo w zbiornikach wewnętrznych) przy schowanym podwoziu i kącie skosu skrzydeł $30^{\circ}$, bez podwieszeń środków bojowych na zewnętrznych węzłach mocowania natomiast z belkami bombardierskimi na stanowiskach 1-6.

Tabela 6. Spis urządzeń systemu uzbrojenia wytypowanych do demontażu wraz z ich masą oraz współrzędnymi środka masy (opracowanie własne na podstawie [20])

\begin{tabular}{|c|c|c|c|c|}
\hline Lp. & $\begin{array}{c}\text { Nazwy elementów } \\
\text { do demontażu }\end{array}$ & $\begin{array}{c}\text { Masa } \\
{[\mathrm{kg}]} \\
\end{array}$ & $\begin{array}{l}\text { Współrzędna } x \\
\text { środka masy }[\mathrm{m}]\end{array}$ & $\begin{array}{l}\text { Współrzędna } z \\
\text { środka masy }[\mathrm{m}] \\
\end{array}$ \\
\hline 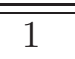 & " Dalmierz laserowy & $\overline{600}$ & $\overline{-1,105}$ & 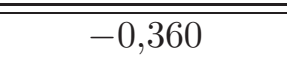 \\
\hline 2 & Agregaty systemu sterowania bronią & 40 & 2,425 & 0,365 \\
\hline 3 & Dwa działka NR-30 & 135 & 4,920 & $-0,220$ \\
\hline 4 & Naboje do działka & 69 & 5,005 & 0 \\
\hline 5 & Wyrzutniki flar & 10 & 5,880 & 0,590 \\
\hline 6 & Belki podkadłubowe 1,2 & 90 & 5,060 & $-0,870$ \\
\hline 7 & Belki podskrzydłowe 3,4 & 64 & 7,000 & $-0,640$ \\
\hline 8 & Belki podskrzydłowe 5,6 & 64 & 3,685 & $-0,480$ \\
\hline \multicolumn{2}{|r|}{ Razem } & 532 & & \\
\hline
\end{tabular}

W tabeli 6 zestawiono masy urządzeń systemu uzbrojenia wytypowanych do demontażu, a ich rozmieszczenie na samolocie ilustruje rys. 6 .

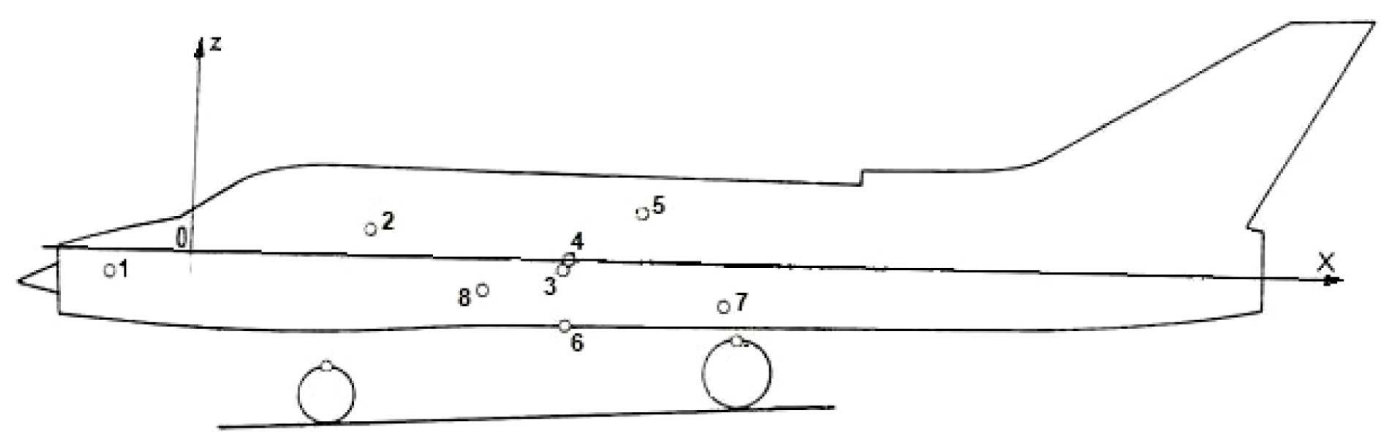

Rys. 6. Rozmieszczenie środków mas zespołów i agregatów samolotu wytypowanych do usunięcia (numeracja poszczególnych środków mas zgodna z pozycjami w tabeli 6) [20]

Jak pokazano w tabeli 6, łączna masa urządzeń, które można zdemontować bez znaczącego wpływu na działanie awioniki samolotu Su-22 w zakresie wykonywania zadań nosiciela, wynosi około $532 \mathrm{~kg}$. Zmniejszenie masy samolotu w konfiguracji bez podwieszania środków bojowych i zewnętrznych zbiorników paliwa, z pilotem oraz zatankowanymi zbiornikami paliwa wewnątrz kadłuba i w skrzydłach, o ww. wartość z pewnością zwiększy udźwig użyteczny tego samolotu i nie wymaga skomplikowanych zabiegów związanych z przebudową systemów samolotu oraz nie wpłynie na bezpieczeństwo lotu. Ponadto, ze względu na fakt, iż ponad $80 \%$ masy urządzeń wytypowanych do usunięcia leży w pobliżu środka masy samolotu $\left(x_{\text {śm }}=6,53 \mathrm{~m}, z_{\text {śm }}=-0,12\right)$ ich usunięcie nie wpłynie znacząco na wyważenie samolotu i prowadzenie $\mathrm{w}$ tym kierunku dodatkowych analiz jest niecelowe. 


\section{Podsumowanie i wnioski}

W ramach rozwoju koncepcji lotniczo-rakietowego systemu wynoszenia niewielkich satelitów na niską orbitę okołoziemską przy wykorzystaniu samolotów MiG-29 oraz Su-22 podjęto się zadania zwiększenia ich udźwigu użytecznego. Stwierdzono, że największe możliwości w zakresie zmniejszenia masy własnej samolotu należy upatrywać w usunięciu elementów jego wyposażenia bojowego. Dokonano analizy możliwości usunięcia elementów systemu sterowania bronią oraz współpracujących z nim urządzeń wykonawczych.

Do elementów najprostszych w demontażu należą belki bombardierskie i wyrzutnie rakiet, gdyż czynności takie wykonywane są podczas normalnej eksploatacji wojskowych statków powietrznych. Można jednakże dodatkowo usunacć elementy montażowe belek i wyrzutni, które znajdują się częściowo wewnątrz skrzydeł samolotu. Spośród integralnych stanowisk broni pokładowej należy zdemontować zarówno działka lotnicze, jak również elementy stanowisk broni strzeleckiej, tj. magazyn amunicji, trakty zasilania amunicją, odprowadzania ogniw i łusek itd. Znaczące możliwości zmniejszenia masy własnej samolotu można również upatrywać w wymontowaniu elementów systemu sterowania bronią, które znajdują się w lukach samolotu i nie są przydatne $\mathrm{w}$ realizacji misji wybranych samolotów jako nosicieli rakiety kosmicznej. Należy jednak pamiętać, iż systemy nawigacyjno-celownicze ww. samolotów są silnie zintegrowane, a konieczność realizacji zadań nawigacyjnych i potrzeba zachowania integralności systemu wyklucza możliwość demontażu kluczowych elementów tych systemów. Inna sytuacja natomiast ma miejsce w przypadku systemów sterowania bronią, których rola sprowadza się do zarządzania stanowiskami broni, a ich zasilanie jest włączane jedynie podczas realizacji zadania z użyciem środków bojowych. Demontaż stanowisk broni pokładowej powoduje brak konieczności posiadania aparatury sterującej ich działaniem. Ponadto, system sterowania bronią nie jest źródłem sygnałów i informacji koniecznych do wykonywania zadań w zakresie „nawigacja”, przez co ich usunięcie nie powinno wpłynąć negatywnie na realizację zadań pilotażowo-nawigacyjnych.

Przeprowadzona analiza wyposażenia samolotów MiG-29 oraz Su-22 pod kątem możliwości demontażu elementów, które nie będą miały istotnego wpływu na funkcjonowanie systemu pilotażowo-nawigacyjnego oraz systemu sterowania lotem statku powietrznego, wykazała, że możliwe do usunięcia są następujące grupy:

- stanowiska broni bombardierskiej i rakietowej (belki i wyrzutnie) oraz elementy węzłów podwieszeń;

- działka lotnicze oraz elementy stanowisk broni strzeleckiej;

- elementy systemu zakłóceń pasywnych;

- urządzenia elektroniczne (bloki) systemu sterowania bronią;

- urządzenia fotokontrolne (dla MiG-29) lub dalmierz laserowy (dla Su-22).

Wykorzystując dokumentację techniczną rozważanych samolotów, dokonano szczegółowej analizy ww. systemów uzbrojenia w aspekcie ich demontażu, a wyniki prac zebrano w tabeli 1 dla MiG-29 oraz w tabeli 7 dla Su-22. W przypadku samolotu Mig-29 stwierdzono możliwość demontażu $259 \mathrm{~kg}$ wyposażenia dla tzw. konfiguracji gładkiej bez podwieszeń (bez belek i wyrzutni), z pilotem oraz zatankowanymi integralnymi zbiornikami paliwa. W przypadku samolotu Su-22 łączna masa urządzeń, które można zdemontować wynosi $532 \mathrm{~kg}$ w konfiguracji bez podwieszania środków bojowych, natomiast z belkami bombardierskimi na 1-6 punkcie podwieszenia, z pilotem oraz zatankowanymi integralnymi zbiornikami paliwa.

W ramach niniejszej pracy dokonano również obliczeń wyważenia samolotu MiG-29 po usunięciu ww. elementów. Do tego celu wykorzystano model masowy CAD samolotu (opracowany w systemie NX), który uwzględnia zarówno elementy struktury, napędu, jak również awioniki i wyposażenia samolotu MiG-29. Wyznaczono położenie środka masy samolotu dla dwóch konfiguracji masy samolotu. W przypadku samolotu z pilotem oraz napełnionymi zbiornikami paliwa, 
wypadkowy środek masy samolotu osiąga 26,8\% średniej cięciwy aerodynamicznej. Po demontażu zaproponowanej części wyposażenia bojowego samolotu środek masy całego obiektu misyjnego wędruje do $28 \%$ średniej cięciwy aerodynamicznej. Dozwolony przedział wędrówki środka masy samolotu MiG-29 zawiera się w granicach 23,7\%-30,5\% MAC. Stąd też można stwierdzić, że jego przemieszczenie po demontażu wybranych elementów zawiera się w „bezpiecznym” zakresie. Wędrówka środka masy jest nieznaczna, co jest pożądane, gdyż charakterystyki sterowności obiektu misyjnego nie ulegają dużym zmianom. W przypadku samolotu Su-22 stwierdzono, iż ponad $80 \%$ masy urządzeń wytypowanych do usunięcia leży w pobliżu środka masy samolotu, a ich usunięcie nie wpłynie znacząco na wyważenie samolotu. Podjęto więc decyzję, iż prowadzenie w tym kierunku dodatkowych analiz jest niecelowe.

Praca jest efektem realizacji etapu Grantu Badawczego nr 13-989/2018/WAT pt. „Lotniczo-rakietowy system wynoszenia tadunków na niska orbite okołoziemska - studium realizowalności", finansowanego ze środków Ministerstwa Obrony Narodowej, a wykonywanego w Wojskowej Akademii Technicznej od 2018 r.

\section{Bibliografia}

1. Scotт J., NOTSNIK, Project Pilot \& Project Caleb, w: aerospaceweb.org [online], 2006, [dostęp 08.09.2020],http://www.aerospaceweb.org/question/spacecraft/q0271.shtml

2. Pilot (NOTSNIK), w: Directory of U.S. Military Rockets and Missiles. Appendix 4: Undesignated Vehicles [online], 2003, [dostęp 08.09.2020], http://www.designation-systems.net/dusrm/app4/notsnik.html

3. NOTS-EV-1 Pilot, w: Wikipedia, The Free Encyclopedia [online], [dostęp 08.09.2020], https://en.wikipedia.org/wiki/NOTS-EV-1_Pilot

4. Glenshaw P., The First Space Ace. F-15 vs. Satellite, w: Air \& Space Magazine [online], 2018, [dostęp 08.09.2020], https://www.airspacemag.com/military-aviation/first-space-ace-180968349/

5. ASM-135 ASAT, w: Wikipedia, The Free Encyclopedia [online], [dostęp 08.09.2020], https://en.wikipedia.org/wiki/ASM-135_ASAT

6. Pegasus. Patented Air Launch System w: Northrop Grumman [online], [dostęp 08.09.2020], https://www.northropgrumman.com/Capabilities/Pegasus/Documents/Pegasus_Factsheet.pdf

7. Pegasus (rocket), w: Wikipedia, The Free Encyclopedia [online], [dostęp 08.09.2020], https://en.wikipedia.org/wiki/Pegasus_(rocket)

8. Pegasus User's Guide, Orbital ATK, [online], 2015, [dostęp 08.09.2020], https://web.archive.org/web/20170623144151/http://www.orbitalatk.com/flight-systems/spacelaunch-vehicles/pegasus/docs/Pegasus_UsersGuide.pdf

9. Chen T., Ferguson P., Deamer D., Hensley J., Responsive Air Launch Using F-15 Global Strike Eagle, w: 4th Responsive Space Conference, [online], 2006, [dostęp 08.09.2020], http://citeseerx.ist.psu.edu/viewdoc/download?doi=10.1.1.560.4885\&rep=rep1\&type=pdf

10. Stratolaunch Systems, w: Wikipedia, The Free Encyclopedia [online], [dostęp 08.09.2020], https://en.wikipedia.org/wiki/Stratolaunch_Systems

11. Dobrzyński P., Machowski B., Olejnik A., Zalewski P., Koncepcja wspomaganego lotniczo rakietowego systemu wynoszenia mini- i mikrosatelitów, Mechanik, 7, 2018

12. Olejnik A., Kiszkowiak L., Dziubiński A., Zalewski P., Machowski B., Dobrzyóski P., Analiza aerodynamiczna samolotu odrzutowego pod kątem wykorzystania do wynoszenia mini i mikro satelitów, Materiały konferencji „Nasze Stulecie, Nauka dla Obronności”, Wydawnictwo Politechniki Poznańskiej, Poznań, 2018, s. 407-423

13. Olejnik A., Dobrzyński P., Machowski B., Zalewski P., Aspekty bezpieczeństwa lotniczorakietowego systemu wynoszenia nano i mikro satelitów, Materiaty konferencji „Wyzwania i rozwój obrony powietrznej Rzeczypospolitej Polskiej”. Obronność RP XXI wieku, Dęblin, 2018, s. 291-306 
14. Wojskowa Akademia Techniczna, sprawozdania etapowe z realizacji Grantu Badawczego nr 13989/2018/WAT pt. „Lotniczo-rakietowy system wynoszenia ładunków na niską orbitę okołoziemską - studium realizowalności", Warszawa, 2019

15. Przeglad Konstrukcji Lotniczych 6-MiG-29, Agencja Lotnicza ALTAIR Ltd., Warszawa, 1992

16. Adamski M., Analiza możliwości bojowych samolotów F-16 i MiG-29 [dostęp 08.09.2020], https://docplayer.pl/18295046-Analiza-mozliwosci-bojowych-samolotow-f-16-i-mig-29-analysis-off-16-and-mig-29-combat-capabilities.html

17. BARTnicki P., Modelowanie geometrii lotniczo-rakietowego systemu wynoszenia ładunków orbitalnych do parametryzacji wybranych własności aeromechanicznych, Praca magisterska, promotor R. Rogólski, WAT Warszawa, 2020

18. Aircraft Weight and Balance Handbook (FAA-H-8083-1B), U.S. Department of Transportation, Federal Aviation Administration, Oklahoma City 2016, [online], [dostęp 08.09.2020], https://www.faa.gov/regulations_policies/handbooks_manuals/aviation/media/faa-h-8083-1.pdf

19. Technisches Handbuch. Grundmasse und Ladedaten MiG-29, Luftwaffenmaterialkommando, 1994

20. Sprawozdanie z realizacji pracy umownej Opracowanie metodyki pomiarów wspótrzędnościowych samolotu Su-22 na potrzeby opracowania modelu w systemie CAD - cz. I, Kierownik pracy: A. Olejnik, WAT, Warszawa, 2004

21. Uzbrojenie polskich F-16, SU-22 I MIG-29, strona www [dostęp 08.09.2020], https://gdziewojsko.wordpress.com/2015/07/30/uzbrojenie-polskich-f-16-su-22-i-mig-29/

22. Samolot Su-22M4, Książka 7, Uzbrojenie Część I, Opis techniczny i działanie, System sterowania bronią, uzbrojenie strzeleckie, uzbrojenie bombardierskie, Dowództwo Wojsk Lotniczych, sygnatura Lot. 2875/90, Poznań, 1991

\section{Analysis of the possibility of payload increasing of MiG-29 and Su-22 aircraft for purposes of an airborne system for launching small satellites to low Earth orbit}

The work is the next stage in the development of the concept of an aircraft-missile system for launching small satellites to low Earth orbit using MiG-29 and Su-22 aircraft. As a part of this stage, the task of analyzing the possibility of increasing the payload of these aircraft was undertaken. It was found that this target could be achieved by reducing mass of the aircraft by removing elements of its combat equipment. The possibility of dismantling components that will have no significant impact on the operation of the sighting-navigation system and the aircraft flight control system was considered. Using the technical documentation of the aircraft concerned, a detailed analysis of these weapons systems was carried out with regard to their dismantling, and the results of the work were summarized in tables. The balance of MiG-29 aircraft after the removal of the selected components was also examined. For this purpose, a CAD model of the aircraft developed in the NX system was used. It was calculated that after dismantling the proposed part of the aircraft combat equipment, the center of mass of the entire mission facility went up to $28 \%$ of the average aerodynamic chord, which is within the allowed range (23,7\%-30,5\% MAC). In the case of Su-22 aircraft, it was found that more than 80 per cent of weight of the equipment to be removed lied close to the center of mass of the aircraft, thus its removal will not significantly affect the balance of the aircraft. 